\title{
EXTERNAL EMPLOYER BRANDING OF SUSTAINABLE ORGANIZATIONS
}

\author{
Joanna MACALIK $\mathbb{D}^{1}$, Adam SULICH $\mathbb{D}^{2 *}$ \\ ${ }^{I}$ Department of Marketing Management, Faculty of Economic Sciences \\ ${ }^{2}$ Department of Strategy and Management Methods, Faculty of Management, Computer Science and Finance \\ Wroclaw University of Economics, 118-120 Komandorska Street, 53-345 Wroctaw, Poland \\ "E-mail: adam.sulich@ue.wroc.pl
}

\begin{abstract}
Purpose - the purpose of the article is to examine whether and to what extent selected Polish companies implement so-called "green employer branding" in communication with their external stakeholders.

Research methodology - the article consists of the theoretical part, which uses the critical analysis of the scientific literature on both green or sustainable organizations and external employer branding; and the practical part, which uses the case study method and content analysis of companies' websites, job advertisements, and social media.

Findings - the main results of the conducted research concern the scope, tools, and methods of creating a green employer brand of Polish enterprises. The conducted case study and content analysis showed that Polish enterprises consciously manage their employer brand, emphasizing the ecological aspects of their business activities. The obtained results complement knowledge in the area of management sciences with detailed conclusions regarding the green employer branding.
\end{abstract}

Research limitations - the conducted analysis is a preliminary examination. Its limitations are primarily related to the methods used for qualitative research, as well as a limited research sample. In the future, such limitations might be overcome by using quantitative research methods and the extension of the research sample.

Practical implications - the results of the research constitute a set of good practices in the field of green employer branding. The formulated model can help formulate the strategy of external employer branding.

Originality/Value - presented research is very first attempt to describe employer branding actions in the aspect of green management in Poland.

Keywords: CSR, green jobs, sustainable organization, green branding, external employer branding.

JEL Classification: M14, M31, Q56, Q57.

Conference topic: Contemporary Organizations Development Management.

\section{Introduction}

The increasing human interference in the natural environment and subjugation of nature on a global scale result in negative consequences and the growing ecological crisis, which causes the inability to maintain human activity within limits safe for man and nature (Wielewska, 2019). Nowadays, the growing awareness regarding ecological issues concerns not only consumers but also employees. For this reason, enterprises, as part of their employer branding activities, try to communicate that they create ecological and "green" workplaces or green jobs. This trend is also noticeable in Poland. In the scientific literature, there is a discussion about key topics for green management and green economy theory. These subjects of discussion are green jobs and sustainable or green organization characteristics (Bartkowiak, 2016). It is not clear whether and to what extent selected Polish companies to implement so-called "green employer branding" in communication to their external stakeholders, and this became the main reason for the preliminary study.

Due to the easy access to information, it is increasingly difficult to hide from the public (stakeholders) inconvenient facts related to the functioning of the company (Bartkowiak, 2016). Transparency in information involves managers of enterprises, who are aware of these impact on companies financial condition (Michalski, 2012), and they attempt to find a way to prevent or eliminate these problems at the earliest possible stage (Grudziński \& Sulich, 2018).

A proper proecological strategy can give the whole enterprise the competitive advantage, also in the aspect of external employer branding of sustainable organizations (Stańczyk-Hugiet, 2009). Therefore, communication is the most important to set a proper strategy or formulate business model. 
The purpose of the article is to examine whether and to what extent selected Polish companies implement socalled "green employer branding" in communication with their external stakeholders, especially job candidates. This study consists of the theoretical part, which used the critical analysis of the scientific literature on both green or sustainable organizations and external employer branding; and the practical part, which used the case study method and content analysis of companies' websites, job advertisements, and social media.

\section{Sustainable development}

Sustainable development is a widely accepted scientific concept of development, which influenced management as sustainable (or green) management (Loknath \& Abdul Azeem, 2017). This concept is implemented in various levels of development, through national, regional to local (Bartniczak, 2019). Also, modern enterprises need to change to survive in a vibrant business environment and to gain a competitive advantage (Tutaj, Rutkowska, \& Sulich, 2019).

Sustainable development is a development that meets the needs of the present without compromising the ability of future generations to meet their own needs (The World Commission on Environment and Development, 1987). In its essence, sustainable development is a process of change in which the exploitation of resources, the direction of investments, the orientation of technological development and institutional change are all in harmony and enhance both current and future potential to meet human needs and aspirations (Bartniczak, 2019). The concept of sustainable consumption and production assumes that the development of societies is based on the principles of justice in the social dimension, respect for existing resources and care for future generations. However, this idea collides with the reality of the modern world, within which the diversity of the standard of living is promoted by increasing consumption and production, thereby bringing adverse effects on the environment (Goryńska-Goldman, 2019).

Despite many years of research and discussions, the sustainable development concept has not received any clear and uniform definition. One of the most frequent inaccuracies and simplifications is reducing sustainable development to environmental or ecological aspects (Pawłowski, 2011). Sustainability in the enterprise is the need to maintain the company's ability to continuously and sustainably develop, regardless of the situation in its macro-environment (Hejduk, 2016). Sustainability is based on the principles of a holistic, ever-growing view of reality, reflection, cooperation, openness to change, learning, trust. It is also achieving the recently formulated theoretical model of a sustainable organization.

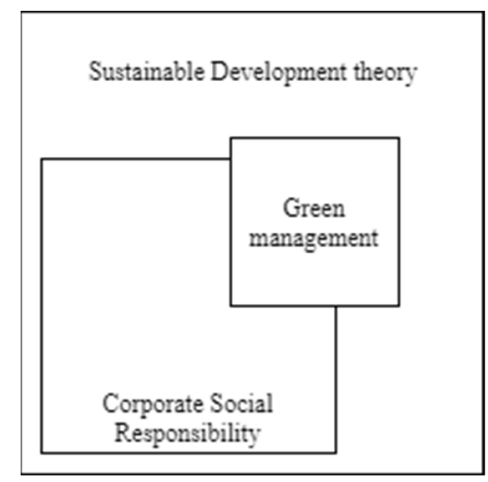

Figure 1. Sustainable development idea and other concepts relations (source: authors' elaboration)

The relations between the sustainable development concept and other ideas are presented in Figure 1. Green management is part of the Corporate Social Responsibility but also can be a separate idea.

\section{Sustainable organizations}

Many factors determine the effective management of organizations, and some of them can be identified as knowledge transfer and information (Sulich, 2018). Many companies creating or modifying their management systems make knowledge available and often decide to implement an environmental management system to become a more sustainable organization. Looking at the development of environmental management systems built on knowledge and information from the external environment (Kulhánek \& Sulich, 2018), one can see the continuous evolution and development of this system aimed at building a smart and sustainable organization (Bartkowiak, 2016).

The sustainable organization is the effect of the long-time evolution of different concepts of managing companies, such as lean management, can successfully meet the assumptions of traditional environmental management systems without creating complex and costly structures (Laszlo, 2008). The sustainable organization is also an effect of the change in business management with the approach "end of pipe" on the approach "from the source" (Bartkowiak, 2016). 
Sustainable company value depends on its ability to meet its needs profitable customers, at simultaneous fulfillment of social expectations. This is why managers must be able to gradually address issues that give value to stakeholders in the strategic planning process along the entire length of the business and financial value chain - which became principles in corporate social responsibility (Demków \& Sulich, 2018). This skill will enable them to build sustainable value based on economic, social and environmental results.

The sustainable organization can be defined as the organization of future which goal is the same as the sustainable development (Laszlo, Sherman, \& Whalen, 2006). Sustainable and durable development is "a course of inevitable and desirable economic development which does not affect the human environment in a significant and irreversible manner, does not lead to degradation of the biosphere, and reconciles the laws of nature, economics and culture" (Poskrobko, 1996).

\subsection{Green management}

Green management aim is to support ecological, pro-ecological or environmental management provided by companies, and to support environmental management by the government. This kind of management is visible mainly in green jobs and green processes and products. Green management is an initiative aiming at continuously improving the foundation of environmental management, such as the development of personnel responsible for environmental activities, environmental management systems, and environmental communication as well as conservation of biodiversity.

This approach is visible as the oppositions to classical systems, where waste becomes a problem when it physically exists (Bartkowiak, 2016). In green management, waste is classified as everything that does not bring the value added to production. Therefore, green management is close to the idea of lean management, where perfection is the ultimate goal. Pro-ecological tools can be divided into three categories: instruments in the form of standards and regulations, control and repression instruments (Table 1).

Table 1. Instruments of pro-ecological management (source: Authors' elaboration based on (Marciniuk-Kluska, 2013))

\begin{tabular}{|c|c|c|}
\hline $\begin{array}{l}\text { Instruments in the form of standards } \\
\text { and regulations }\end{array}$ & Stimulating instruments & Control and repression instruments \\
\hline $\begin{array}{l}\text { - Product and process standards (appli- } \\
\text { cation of recovery and recycling, } \\
\text { manufacture of products from safe } \\
\text { substances) } \\
\text { - Atmospheric air quality standards } \\
\text { - Water quality standard } \\
\text { - Soil quality standards } \\
\text { - Permits for entering sewage into wa- } \\
\text { ters or land } \\
\text { - Permission for waste generation } \\
\text { - Permits for the introduction of gases } \\
\text { and dust } \\
\text { - Noise emission license } \\
\text { - Concessions for natural mining re- } \\
\text { sources } \\
\text { - New technological standards (use of } \\
\text { low-waste technologies, the low fail- } \\
\text { ure rate of manufactured products) }\end{array}$ & $\begin{array}{l}\text { - Subsidies for pro-environmental ac- } \\
\text { tivities } \\
\text { - Tax breaks } \\
\text { - Preferred loans (a sub-holder in the } \\
\text { form of a difference in interest rates) } \\
\text { - Subventions for a specific type of ac- } \\
\text { tivity leading to an improvement of } \\
\text { the environment } \\
\text { - Ecological insurance against legal lia- } \\
\text { bility for environmental pollution }\end{array}$ & $\begin{array}{l}\text { - Legal actions aimed at forcing com- } \\
\text { pliance with environmental protection } \\
\text { requirements } \\
\text { - Charges for the emission of pollutants } \\
\text { into the environment } \\
\text { - Inspections to determine the level of } \\
\text { compliance with environmental regu- } \\
\text { lations } \\
\text { - Negotiations with entities violating } \\
\text { the environmental regulations in order } \\
\text { to direct actions that meet specific } \\
\text { standards and regulations } \\
\text { - Fees for using the environment (e.g., } \\
\text { cutting trees and shrubs) } \\
\text { - Product charges (for placing in public } \\
\text { trading or using). It applies to prod- } \\
\text { ucts causing pollution in one of the } \\
\text { product life phases } \\
\text { - Service fees (e.g., for sewage dis- } \\
\text { posal, waste disposal) }\end{array}$ \\
\hline
\end{tabular}

Environmental management is the management of use, protection and shaping the environment towards sustainable development. This management is implemented directly and indirectly, primarily in decision-making processes. This type of management occurs in layouts of territorial units and economic units. Green management takes place when there is an integration of management with the general management system in the organization. In a profitoriented organization, environmental management occurs when a system in the form of the EMAS or ISO 14001 standard is applied. Therefore, the management system of the natural environment should be understood as a separate and adequately ordered part a reality that is related to the management of user processes, protection and shaping the natural environment in the scale of the state, region, commune as well as in the scale of economic organization. 


\subsection{Green jobs}

Green jobs are places of employment that contribute to preserve or restore the environment, applied in traditional sectors such as manufacturing and construction, or in new, emerging sectors such as renewable energy and energy efficiency (Rutkowska-Podołowska, Sulich, \& Szczygieł, 2016; UNEP, 2008).

Green jobs are created in connection with undertaking non-investment and investment projects, the effect of which is to reduce the pressure on the natural environment on the part of the economy and consumption. They may arise in any sector of the economy (Rutkowska-Podołowska \& Sulich, 2016). However, it is a prerequisite that the employed are directly or indirectly involved in improving the environment in a given area and in counteracting projects harmful to nature, both in the short and long term. Thus, green jobs are mentioned when they are accompanied by activities that create goods and services to determine the size, prevention, reduction, minimization or repair of damage to the environment related to water, air, and soil, as well as activities related to waste issues, noise or ecosystems (Ryszawska, 2016; UNEP, 2008). Green jobs are created mainly in such areas as sustainable transport, waste management and recycling, renewable energy, water and sewage management, water supply, organic farming and improvement of the energy efficiency of buildings (Sulich, 2017). However, there is no field of the economy that has no impact on the natural environment. What is more, care for the natural environment, manifested in the savings of resources and raw materials used in the production process or service provision, is often understood as a saving (Deschenes, 2015). Employers, therefore, strive to raise ecological awareness among employees and implement pro-environmental production methods. A green job is any job or self-employment that genuinely contributes to a more sustainable world. At the enterprise level, green jobs can produce goods or provide services that benefit the environment, for example, green buildings or clean transportation (Cecere \& Mazzanti, 2017). For persons beginning their professional career, the meaning and potential of green places for employment are very high. Green jobs idea is an evolving concept and therefore it is difficult to give a strict definition. This dynamic concept is based on the fact that each new product, service or technology might evolve in a more efficient replacement in terms of energy and material consumption, emission and other particle pollution emissions. Therefore, it is relatively complicated to define with clear boundaries what can be considered as a green sector, an eco-industry or green jobs (Sulich \& Zema, 2018).

Green jobs are a solution for young, unemployed people, who not only can find employment but can become entrepreneurs in this sector of the economy. Green jobs can also influence the European integration by programmes of international cooperation and knowledge exchange which aim to reduce youth unemployment and protect the environment (Rutkowska-Podołowska et al., 2016).

Table 2. Key jobs for the green economy sectors based on the example of Polish companies (source: author's research based on NACE rev. 2 classification (European Commision, 2008))

\begin{tabular}{|c|c|c|c|}
\hline $\begin{array}{l}\text { NACE Rev. } 2 \\
\text { category }\end{array}$ & Sector & $\begin{array}{c}\text { Company/ organization } \\
\text { example }\end{array}$ & Profession/job name \\
\hline A & $\begin{array}{l}\text { agriculture, forestry, hunting } \\
\text { and fishing }\end{array}$ & Ekopaczka Society & database administrator \\
\hline \multirow{3}{*}{$\mathrm{D}$} & \multirow{3}{*}{$\begin{array}{l}\text { production and supply of } \\
\text { electricity }\end{array}$} & Tauron Ekoenergia & specialist in fuel cell batteries \\
\hline & & Volkswagen Poland & specialist in fuel cell batteries \\
\hline & & PKP IC & fuel cell engineer; technician; operator \\
\hline \multirow{2}{*}{$\mathrm{E}$} & \multirow{2}{*}{$\begin{array}{c}\text { water supply; sewerage, waste } \\
\text { management, and remediation } \\
\text { activities }\end{array}$} & MPWiK Wrocław & technician; recycling operator \\
\hline & & Alba & recycling and recovery engineer \\
\hline
\end{tabular}

The definition of green jobs should be objective and measurable; the latter of these requirements being particularly problematic for researchers and statistical authorities around the world. Moreover, the literature does not provide a clear definition of green jobs (Rutkowska-Podołowska et al., 2016; Sulich \& Zema, 2018). It is possible to identify categories of green job companies and to evaluate their external employer branding actions as a sustainable organization, based on classification schemes in the Statistical Classification of Economic Activities in the European Community (NACE) (see Table 2).

In addition to the above-defined definition of the so-called green jobs, we can also talk about the general trend of employees' commitment to environmental protection (Figure 2). Nowadays, it is possible to contribute to environmental protection at almost every position - not only thanks to the employee's involvement, but also thanks to participation in social programs implemented by the company. The first step, however, is to recruit employees for whom environmental protection is essential. This is the task of the so-called "green recruiting," together with the external employer branding, which is the subject of this article. 


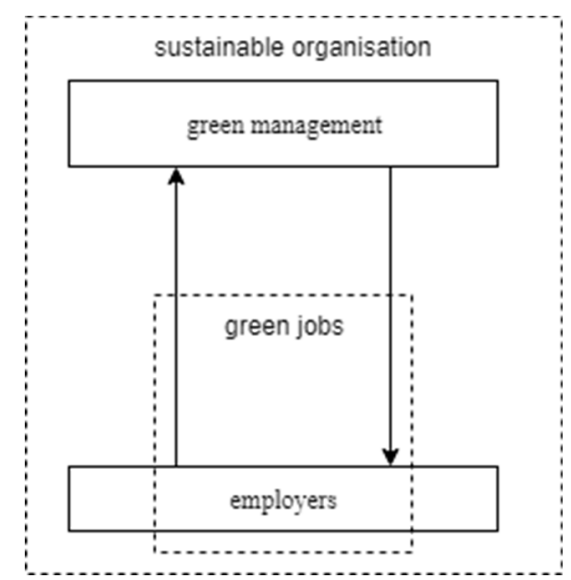

Figure 2. Green jobs as a result of two trends (source: authors' elaboration)

There are the main two opposing trends. First is a result of green management which involves green jobs creation among employers. The second trend is an effect of the internal motivation and commitment to influence the sustainable organization (Figure 2). Green management is also the ability to choose the right strategy, which should include three elements (Bartkowiak, 2016):

- the diagnosis of explaining or defining the nature of the challenges,

- the critical approach to challenges,

- the influence on employees and candidates.

\section{The external employer branding}

Employer branding is one of the growing areas of interest to both academic research and business. In the scientific literature in the field of management sciences, there is - generally - compliance in the way of defining this term (Budzanowska-Drzewiecka, Lipińska, \& Stańczyk, 2013). The concept of employer branding was first introduced in 1996, when S. Barrow and T. Ambler defined it as "package of functional, economic, and psychological benefits provided by employment" (Ambler \& Barrow, 1996, 2013). Since then, the scientific discussion has mainly concerned the scope of employer branding, its tools, as well as the effectiveness of the activities undertaken in this field. Many researchers believe that employer branding refers to at least to two disciplines: human resources management and marketing (Wojtaszczyk, 2015), and the other thing, that there is also third discipline - strategic management (Figurska \& Matuska, 2013).

The subject of the presented article is external employer branding, which is more often considered in the field of marketing science. While internal employer branding is primarily focused on creating a friendly work atmosphere and a possibility of employees' development inside the organization (Stuss, 2016), external employer branding is directed to the organization's environment: professionals, students, graduates and other stakeholders (Stuss \& Herdan, 2017). It is also generally assumed that the employer branding, mainly external, has the same theoretical foundations and tools as the consumer branding and corporate branding (Kantowicz-Gdańska, 2009) and that the most important target group of external employer branding are potential employees of the company (Moroko \& Uncles, 2008). The role of external employer branding is to (1) communicate about enterprise values (employer value proposition - EVP), and thanks to that - to (2) attract desired candidates.

It should be noted that more than 20 years of employer branding practice has made enterprise activities in this area more and more professional. It is believed that modern employer branding is evolving in the direction called 3.0. While employer branding 1.0. aimed at filling jobs and 2.0 - engage employees; employer branding 3.0 objective is to "make the world a better place" (Marchington, 2010). One of the key development directions of employer branding 3.0 - in the opinion of the authors of the presented article - is so-called "green employer branding". By this term, we mean a series of company activities aimed at building its external image as an organization conducting a sustainable business and offering so-called green jobs to employees who share the same values, especially currently entering the labour market "The Generation Z".

\section{4. "The Generation Z" on the labor market}

Representatives of the current entering the labour market "Generation Z" significantly differ from their predecessors (Kuczerska, 2018). The term "Generation Z" refers to those born from 1995 through 2010 (Seemiller \& Grace, 2016). The vast majority of researchers note the Internet entirely shapes first of all that "GenZers" world - they do not know 
life without social media, smartphones, and computers (Kuczerska \& Smoląg, 2018). The primary influence on this generation indeed had the development of modern technologies and social networks, but they are also heavily influenced by a war against terrorism, the economic crisis of the end of the century and - worldwide concern for ecology (Hilčenko, 2016).

Numerous studies confirm that "Generation Z" is "we-generation" and that its representatives are more socially oriented, strongly interested in social problems (Kuczerska \& Smoląg, 2018; Seemiller \& Grace, 2016; ŻarczyńskaDobiesz \& Chomątowska, 2014) and business responsibility and that they engage in worldwide ecological issues like global warming and climate change, alternative energy sources, pollution, water access, animal rights, recycling, deforestation or less waste trend, etc. (Masdar, 2019; Patel, 2017). Conducted in 2016 "Masdar Gen Z Global Sustainability Survey", which revealed the top priority of more than 5000 "GenZers" from 20 countries, states that for $40 \%$ of them a climate change is the top priority, beating out terrorism, economy, unemployment, and poverty (Masdar, 2019). Also, the study clearly shows that the vast majority of respondents, especially in emerging economies, have high demands on the private sector and want to lean towards careers in sustainability (Masdar, 2019). Among other things, for this reason, the concept of "green recruiting" develops in the area of human resources management. So-called "green recruiting" refers to sharing of company's unswerving commitment towards the cause of environment with the candidates whom they are trying to hire and minimizing the negative impact of the recruitment process itself on the environment (Diana, 2016; Gupta \& Gupta, 2013; Sullivan, 2007).

All of the trends listed above also apply to Poland. Polish "GenZers" are people who do not remember the communist era or even the times before the country's entry into the European Union (2004). As well as their peers around the world, Poles born after 1995 are also concerned about ecology (Ministerstwo Finansów, 2019). For this reason, they not only use organic food or clothing or try to live in the zero-waste philosophy but also more and more consciously choose their employer. It is worth noting that CSR gains in importance, which confirms the report "Employer branding in Poland 2018" (HRM Institute, 2018). As the authors of the report inform, social activity is still in the last place among attributes assessed, but this year has already obtained $50 \%$ indications, by as much as six percentage points more than last year. This means that young people entering the labour market want to have an impact on the world around them and more and more often choose companies that they are socially responsible in which they feel that they are doing something good next to rewarding work (HRM Institute, 2018). Therefore, it should be critical that the employer highlights in external employer branding, in addition to other advantages, the fact that the company conducts a sustainable, green activity, offers so-called "green jobs" or work on other positions, by the principles of respect for the natural environment.

\section{External employer branding of sustainable organizations - assumptions of the study}

The condition necessary to ensure the effectiveness of the company is primarily the effective green management thereof (Bartkowiak, 2016). The part of this kind of management is to set coherent activities in communication with the surrounding business environment. This includes communicating with the candidates in order to become so-called "employer of choice" and recruitment of talents; companies have a range of tools at their disposal. These are, especially:

- participation in job fairs and conferences,

- organization of internship programs,

- publication of recruitment ads,

- creation of recruitment campaigns,

- "career" tab on the company's website,

- presence at universities, open days,

- gamification,

- social media.

Due to the enormous importance of the Internet for generation Z, which is currently entering the labour market, online tools have a special significance in today's external employer branding. The Internet is for the "GenZers", together with the opinion of friends and family and own experience, the main source of information about their future employer. Almost 34\% of them get this information from companies' websites (tabs "Career" or "Work") and another $23 \%$ - from social media (Sulich, Zema, Kozikowski, \& Stasiński, 2016). The Internet is also a place, where they are looking for job ads. For this reason, it was decided to focus on the analysis of online tools in this article. The analysis covered three online tools of external employer branding, addressed to candidates for different positions; this is:

- online recruitment ads in the recruitment websites other than employer website,

- "career" tab on the company's website,

- official social media channel(s).

12 enterprises operating in Poland were selected, both with a predominance of domestic and foreign capital, considering the following factors:

- their presence in section "Environment" of "Responsible business in Poland 2017. Good practices" report (Borowska et al., 2017) or employing for green jobs, 
- regularly publishing a social report,

- currently looking for candidates for at least one position (not necessarily for a "green job"),

- representing various business sectors.

As part of the initial diagnosis, out of 12 companies, three were selected, which were analysed using the case study method, with particular emphasis on the analysis of the content transferred via external branding online channels (European Commision, 2008; Sulich \& Zema, 2018).

The purpose of the analysis was to examine:

- to what extent these companies use the external employer branding online tools,

- to what extent these tools contain references to values related to environmental protection.

In order to get answers to the above questions, the case study method and content analysis method were used (see Figure 3). The case study method enables a researcher to closely examine the data within a specific context (Yin, 2017). Case studies have often been viewed as a useful tool for the preliminary, exploratory stage of a research project, as a basis for the development of the "more structured" tools that are necessary for surveys and experiments (Rowley, 2002). Also, the case study method is often combined with the content analysis method, which is a widely used qualitative research technique, intended to interpret meaning from the content of text data (Hsieh \& Shannon, 2005). This method allows the systematic analysis of the text in order to conceptualize and identify the essential features of a given message (Vitouladiti, 2014).

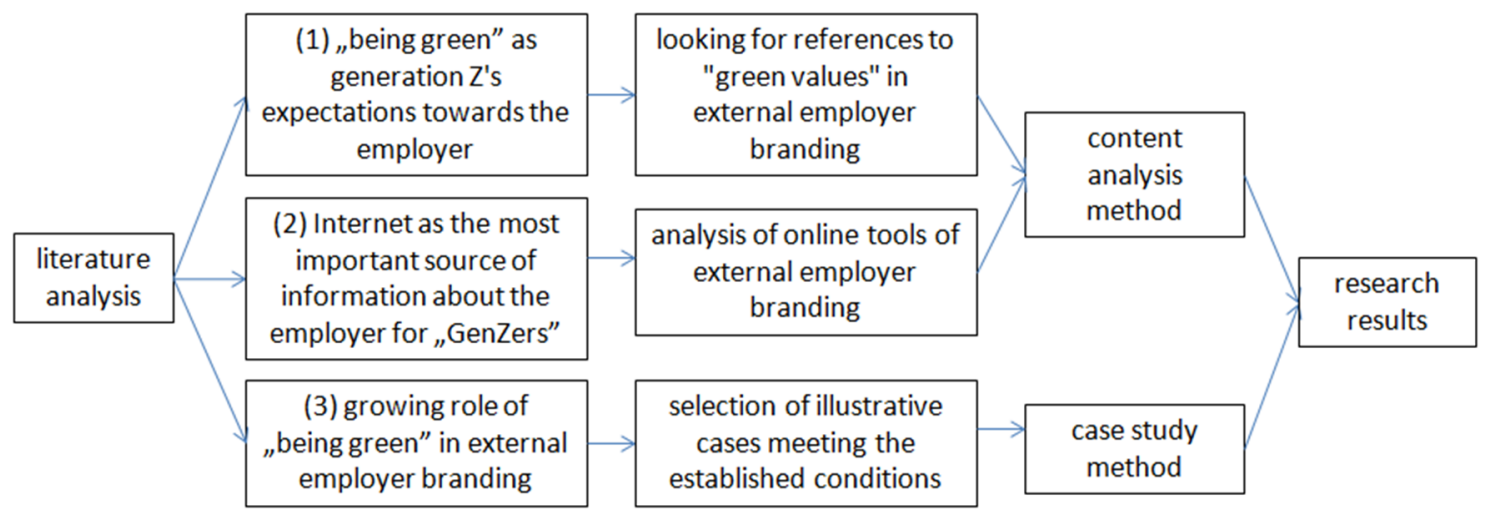

Figure 3. Research procedure (source: Author's elaboration)

\section{External employer branding of sustainable organizations - results of the research}

In Table 3 the results of the analysis of the online external employer branding tools are presented. Companies were examined in two main groups. The first group consists of companies employing on crucial position for the green economy sectors, and the second group was formed of companies selected on the base of "Responsible business in Poland 2017. Good practices" report (Borowska et al., 2017). Among the two formulated in Table 3 two groups important was to indicate whether organizations report their CSR activities. In literature and business practice there is a relationship and even diffusion between the concept of sustainable development and corporate social responsibility.

Based on the analysis presented in Table 3 analysis, three companies were selected that were examined using the in-depth case study method and content analysis method. Due to the volume restrictions regarding the presented article, only the key findings regarding the ways of communicating about sustainable development in external employer branding will be presented below.

The Tauron Group is one of the largest business entities in Poland, with its capital of approximately PLN 16 billion and employs approximately 25,000 employees. The company is also the largest distributor of electricity in Poland (Tauron, 2019a) and operate in difficult fuel and energy industry. Tauron Group engages in some projects for the environment, such as educational and charity activities. It is a sponsor of significant cultural and sporting events and cooperates, among others, with the Mountain Volunteer Rescue Service, the National Polish Radio Symphony Orchestra, and the Polish Olympic Committee. Tauron's mission is: "With passion and commitment, we provide modern solutions that give energy in an ever-changing world". Among the more than 25,000 employees of the Tauron Group, people are representing different generations - from the generation of baby boomers (1946-1964) through the generation Y (1980-1989), and even Z (after 1990) (Marka Pracodawcy, 2019). The company has a strong personnel department supporting managers not only in managing human resources and internal employer branding but also in creating the external employer's brand. Tauron uses innovative and extensive external employer branding tools and is visible as an employer on the Internet. However, even though in corporate branding the company emphasizes the topic of its sustainable development and CSR, it is not strongly visible in employer branding. Both in job advertisements and posts on social media addressed to candidates, the advantage of sustainable activity is not emphasized. A brief 
reference to the company's value appears in the tab for candidates on the website, but there are no direct references to environmental protection among these values, even though it is one of the main elements of the TAURON Group's sustainable development strategy adopted by the company for the years 2017-2025 (Tauron, 2019b).

Table 3. Online external branding tools of the sustainable organization - analysis of selected organizations

\begin{tabular}{|c|c|c|c|c|c|}
\hline \multicolumn{6}{|c|}{$\begin{array}{l}\text { Companies employing on crucial position for the green economy sectors NACE rev. } 2 \text { classification } \\
\text { (European Commission, 2008) }\end{array}$} \\
\hline $\begin{array}{l}\text { Organiza- } \\
\text { tion name }\end{array}$ & $\begin{array}{l}\text { Current CSR } \\
\text { report }^{1}\end{array}$ & $\begin{array}{l}\text { Job adver- } \\
\text { tisements }\end{array}$ & $\begin{array}{l}\text { A tab for candidates } \\
\text { on official website }\end{array}$ & Social media ${ }^{3}$ & Comments \\
\hline $\begin{array}{l}\text { Tauron } \\
\text { Group }\end{array}$ & $\checkmark$ & $\checkmark$ & $\checkmark$ & $\begin{array}{l}\text { Facebook } 82610 \\
\text { LinkedIn } 6504\end{array}$ & $\begin{array}{l}\text { In addition to job offers, the } \\
\text { candidate's section contains in- } \\
\text { formation about the company's } \\
\text { values. }\end{array}$ \\
\hline $\begin{array}{l}\text { Volkswagen } \\
\text { Poland }\end{array}$ & $\checkmark$ & $\checkmark$ & $\checkmark$ & $\begin{array}{c}\text { Facebook } \\
33799764 \\
\text { YouTube } 8269 \\
\text { Instagram } 2692 \\
\text { LinkedIn }\end{array}$ & \\
\hline PKP IC & $\checkmark$ & $\checkmark$ & $\begin{array}{c}\checkmark \\
\text { "Work" }\end{array}$ & $\begin{array}{c}\text { Twitter } 7982 \\
\text { Facebook } 194654 \\
\text { Instagram } 12365 \\
\text { YouTube } 3085\end{array}$ & \\
\hline MPWiK & $\checkmark$ & $\checkmark$ & $\begin{array}{c}\checkmark \\
\text { "Work with us" }\end{array}$ & $\begin{array}{l}\text { Twitter } 1018 \\
\text { Facebook } 6046 \\
\text { Facebook group } \\
\text { "Work with us" }\end{array}$ & $\begin{array}{l}\text { An extensive "Work with us" } \\
\text { tab - containing, among others, } \\
\text { the "Get to know us" section } \\
\text { and the code of ethics. }\end{array}$ \\
\hline $\begin{array}{l}\text { WPO Alba } \\
\text { S.A. }\end{array}$ & $\checkmark /$ global & $\checkmark$ & $\begin{array}{l}\checkmark \\
\text { "Work in Alba in } \\
\text { Poland" }\end{array}$ & - & \\
\hline \multicolumn{6}{|c|}{ Companies selected on the base of 'Responsible business in Poland 2017. Good practices" report } \\
\hline $\begin{array}{l}\text { Organiza- } \\
\text { tion name }\end{array}$ & $\begin{array}{l}\text { Current CSR } \\
\text { report }^{1}\end{array}$ & Job ads & $\begin{array}{l}\text { A tab for candidates } \\
\text { on official website }{ }^{2}\end{array}$ & Social media3 & Comments \\
\hline $\begin{array}{l}\text { Raben } \\
\text { Group }\end{array}$ & $\checkmark$ & $\checkmark$ & $\begin{array}{l}\checkmark \\
\text { "Employees" }\end{array}$ & $\begin{array}{l}\text { LinkedIn } 8277 \\
\text { Facebook } 30680\end{array}$ & \\
\hline Enea Group & $\checkmark$ & $\checkmark$ & $\checkmark$ & $\begin{array}{c}\text { YouTube } 1078 \\
\text { Facebook } 21186 \\
\text { LinkedIn } 2911 \\
\end{array}$ & $\begin{array}{l}\text { Extensive "Career" tab with the } \\
\text { "Get to know us" section. }\end{array}$ \\
\hline PKN Orlen & $\checkmark$ & $\checkmark$ & $\checkmark$ & $\begin{array}{c}\text { Facebook } 142780 \\
\text { Twitter } 13425 \\
\text { Instagram } 7590 \\
\text { LinkedIn } 18802 \\
\end{array}$ & $\begin{array}{l}\text { In the "Career" tab, the sub-tab } \\
\text { "Who we are". }\end{array}$ \\
\hline $\begin{array}{l}\text { Skanska Po- } \\
\quad \text { land }\end{array}$ & $\checkmark$ & $\checkmark$ & $\checkmark$ & $\begin{array}{c}\text { LinkedIn } 5293 \\
\text { Instagram } 1138 \\
\text { Facebook } 12056 \\
\end{array}$ & \\
\hline $\begin{array}{l}\text { Zywiec } \\
\text { Group }\end{array}$ & $\checkmark$ & $\checkmark$ & $\checkmark$ & $\begin{array}{c}\text { Instagram } 1185 \\
\text { Facebook } 14527 \\
\text { LinkedIn } 7550 \\
\end{array}$ & $\begin{array}{l}\text { the company awarded for activi- } \\
\text { ties for its internal and external } \\
\text { employer branding programmes }\end{array}$ \\
\hline $\mathrm{CCC}$ & $\checkmark$ & $\checkmark$ & $\checkmark$ & $\begin{array}{l}\text { Facebook } 607275 \\
\text { YouTube } 4595 \\
\text { Instagram } 124430\end{array}$ & $\begin{array}{l}\text { Extensive "Career" tab with the } \\
\text { "Know us" section. }\end{array}$ \\
\hline Polpharma & $\checkmark$ & $\checkmark$ & $\checkmark$ & LinkedIn 14551 & Extensive "Career" tab. \\
\hline
\end{tabular}

Source: Authors own elaboration; symbol meaning: 1 - also included reports for the capital group to which the enterprise belongs, 2 - also if global, 3 - with the names of individual social media the number of followers was given, only social media that have over 1000 followers are included (number on 20/02/2019). If a number written in italics - means the number of followers on a global scale. 
Municipal Waterworks and Sewerage System in Wroclaw - MWPiK we Wroclawiu is a public company employing nearly 700 employees (MPWiK, 2019a). The necessary task of MPWiK is to ensure the continuity of supplies of high-quality water and the reliability of sewage collection services (MPWiK, 2019b) and the mission is: "Service for the community of Wrocław and support for the development of the city". The company implements a sustainable development strategy and conducts extensive, award-winning activities in the field of corporate social responsibility (MPWiK, 2019a). Due to the continuous development of the city, the company also conducts intensive recruitment. Worth noting is the extensive "Work with us" tab, which consists of the following tabs: "Frequently asked questions", "Projects", "Get to know us", "Benefits", "Areas", "Offers". In the "Projects" section, candidates can find out more about the company's internal projects, mostly focused on environmental protection. In the "Get to know us" section, the information about the company's values and code of ethics can be found. An interesting way to reach candidates is the group established by MPWiK on the Facebook social network under the name "Work with us" (currently 214 members). Even though environmental protection and supporting the sustainable development of the city are among the MPWiK's priority activities, this is not an asset displayed in the content directed to candidates - both in social media, job offers and in the tab on the website.

Grupa Żywiec (Zywiec group) is one of the leading beer producers in Poland with the broadest portfolio of 13 styles of beer, 12 brands, and over 40 products. Żywiec is associated with the worldwide Heineken Group. Grupa Żywiec is the only company among beer producers in Poland, listed on the Warsaw Stock Exchange, where it debuted in 1991(Grupa Żywiec, 2019a). The Żywiec Group implements an extensive employer branding program (e.g., "Talent Brewery", associated with apprenticeships and internships). Its online elements are a special website dedicated to the company as an employer and an actively run fan page, which publishes not only job advertisements, but also publications on the brand's value, its development strategy and general information on the labor market (Prószynski, 2019). In "Meet us" tab of "Career" section on the company website the films with the opinions of current employees are presented, as well as the recruitment process and benefits resulting from employment. As in previous cases, sustainable development is one of the company's business priorities (Grupa Żywiec, 2019b), but this is only slightly emphasized in the communication addressed to candidates, where the other advantages are prevalent.

This study was a preliminary study whose aim was to check if the green sector employer announces their green strategy to the potential employees, with particular emphasis on online communication channels. Research conducted among students (Sulich et al., 2016; Zbaraszewski, 2011) presents outcomes on ecological awareness among Polish candidates who became greater, and it is possible to indicate among $\mathrm{Z}$ generation a group of green jobs candidates (Sulich, 2017). The results obtained by other authors based on development in environmental education or sustainable development education proved that information transparency is essential in external branding communication processes (Zbaraszewski, 2011). For this reason, information on the green aspects of the company's activity should be visible to the candidates and the so-called external "green employer branding" should be for modern enterprises the subject of particular interest, constituting an essential element of corporate branding and employer branding (Figure 4).

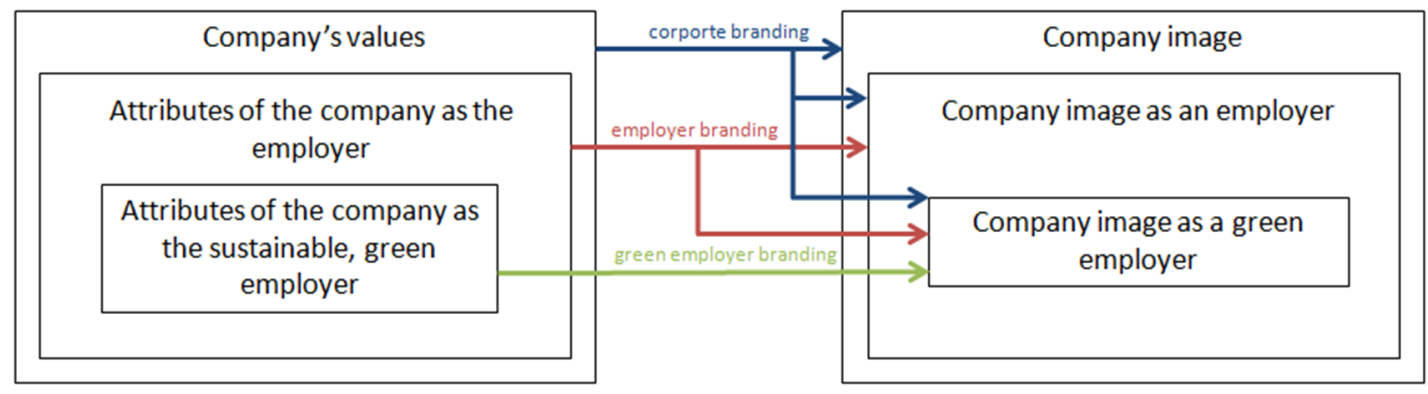

Figure 4. Place of external green employer branding in corporate branding (source: own elaboration based on (Budzanowska-Drzewiecka et al., 2013))

\section{Conclusions and further research}

Presented above, preliminary analysis of the activities in the field of online external branding of selected enterprises operating on the territory of Poland allows for the formulation of several important observations. First, it is unexpected that organizations which are examples of sustainable organizations and belong to the green sector, and offer green jobs, do not advertise their attitude and pro-environmental approach in their external employer branding. After a closer examination of sustainable organizations, we conclude that:

- among the candidates, there is a growing need to care for the environment, also as part of their professional work,

- analyzed organizations focus on activities within general corporate branding - and thus on building an image among all stakeholders, 
- analyzed companies present distinguishing features related to the overall activity of the company, taking into account corporate social responsibility (which sometimes may be extended in environmental dimension),

- analyzed companies use standard online tools of external employer branding, from which the most important are "career" tabs on official websites,

- in employer branding activities of presented companies, to a small extent, the advantages resulting from the sustainable development of the company are presented,

- in external employer branding of the sustainable organization, the opportunity to work with respect for environmental protection and social responsibility is slightly underlined,

- employer branding should be treated not only as an element of HR and corporate branding but also as an element of corporate social responsibility,

- the use of "green employer branding" can contribute to building strong relationships with the candidate.

Summing up, green employer branding can be for green enterprises a tool for reaching a narrow, albeit growing, a group of candidates who are highly qualified on the one hand, and on the other hand - highly interested in working in conditions conducive to environmental protection.

In a situation in which the "employee market" is being talked about in Poland, the opportunity for the employee to work following his environmental protection principles may be a significant differentiator for the company and a method of acquiring competent employees, who share the same values as the company. It should be expected that sustainable organizations will increasingly use the asset of their social responsibility and sustainability not only incorporate branding or green recruiting but also in external employer branding.

The conducted analysis is a preliminary examination. Its limitations are primarily related to the methods used for qualitative research, as well as a limited research sample. In the future, such limitations might be overcome by using quantitative research methods and the extension of the research sample. The authors of the article plan further quantitative, international research on the role of sustainability, green management and environmental protection in external employer branding. It is planned to examine both the importance of these factors for job candidates and the perception of their role by employees responsible for creating the employer branding strategy.

\section{Aknowledgements}

The project is financed by the Ministry of Science and Higher Education in Poland under the programme "Regional Initiative of Excellence" 2019-2022 project number 015/RID/2018/19 total funding amount 10 721 040,00 PLN

\section{References}

Ambler, T., \& Barrow, S. (1996). The employer brand. Journal of Brand Management, 4(3), 185-206. https://doi.org/10.1057/bm.1996.42

Ambler, T., \& Barrow, S. (2013). The employer brand. Journal of Brand Management. https://doi.org/10.1057/bm.1996.42

Bartkowiak, P. (2016). The Environmental Management System as the Element of an Intelligent Manufacturing Company. Journal of Management and Financial Sciences, (24), 101-113.

Bartniczak, B. (2019). Sustainable Development in the Polish-Czech Cross Border Area - Indicators Analysis. In P. Jedlicka, P. Maresova, \& I. Soukal (Eds.), Hradec Economic Days (pp. 19-28). Hradec Kralove: University of Hradec Kralove.

Borowska, M., Górska, M., Joniewicz, T., Kłopotowska, A., Krzyczkowski, K., Marchlewicz, M., Wojciechowicz, E. (2017). Odpowiedzialny biznes w Polsce 2017. Dobre praktyki. Warszawa. Retrieved from http://odpowiedzialnybiznes.pl/wpcontent/uploads/2018/04/Raport2017.pdf

Budzanowska-Drzewiecka, M., Lipińska, A., \& Stańczyk, I. (2013). Ocena działań podejmowanych przez pracodawców w zakresie zewnętrznego Employer Branding w Internecie z perspektywy osób poszukujących pracy. Zarządzanie i Finanse, 1(3), 91105 .

Cecere, G., \& Mazzanti, M. (2017). Green jobs and eco-innovations in European SMEs. Resource and Energy Economics. https://doi.org/10.1016/j.reseneeco.2017.03.003

Demków, K., \& Sulich, A. (2018). Zielone miejsca pracy w perspektywie CSR. Marketing i Rynek, 11(25), 73-84.

Deschenes, O. (2015). Green Jobs. In International Encyclopedia of the Social \& Behavioral Sciences: Second Edition. https://doi.org/10.1016/B978-0-08-097086-8.94025-X

Diana, A. C. (2016). A Study on Effectiveness of Green Recruitment practices among HR Executives of IT sector. IOSR Journal of Business and Management, 1, 8-11.

European Commision. (2008). NACE 2 REV - Regulamento Comissão Europeia No 1893/2006 do Parlamento Europeu e do Conselho. Retrieved from https://ec.europa.eu/eurostat/documents/3859598/5902521/KS-RA-07-015-EN.PDF

Figurska, I., \& Matuska, E. (2013). Employer Branding as a Human Resource Management Strategy. Human Resources Management \& Ergonomics, 7(2), 35-51. 
Goryńska-Goldman, E. (2019). Barriers to the Development of Consumption sustainability: the Consumers' Perspective on the Food Markets. In P. Jedlicka, P. Maresova, \& I. Soukal (Eds.), Hradec economic days (Vol. 9(1), pp. 243-251). Hradec Kralove: University of Hradec Kralove.

Grudziński, A., \& Sulich, A. (2018). Strategic goals of the renewable energy sector. In A. Sulich \& W. Wodo (Eds.), Proceedings of 16th Students' Science Conference "Science is our universe" (pp. 36-44). Boguszów-Górce: Oficyna Politechniki Wrocławskiej.

Grupa Żywiec. (2019a). O firmie. Retrieved from https://grupazywiec.pl/o-firmie/

Grupa Żywiec. (2019b). Zrównoważony rozwój. Retrieved from https://grupazywiec.pl/zrownowazony-rozwoj/

Gupta, G., \& Gupta, A. (2013). Green Recruiting. International Journal of Management \& Information Technology, 3(3), 32-33. https://doi.org/10.24297/ijmit.v3i3.1749

Hejduk, I. K. (2016). Nowe paradygmaty zarządzania - od organizacji inteligentnej do koncepcji sustainable eterprise (przedsiębiorstwa przyszłości). Studia i Prace Kolegium Zarządzania i Finansów, (149), 25-42.

Hilčenko, S. (2016). Who has better functional-logical capacity: Generation "X", "Y" or "Z"? Edukacja-Technika-Informatyka, 7(2), 169-175. https://doi.org/10.15584/eti.2016.2.22

HRM Institute. (2018). Employer Branding w Polsce.

Hsieh, H. F., \& Shannon, S. E. (2005). Three approaches to qualitative content analysis. Qualitative health research. https://doi.org/10.1177/1049732305276687

Kantowicz-Gdańska, M. (2009). Employer branding - kwestie definicji i modelu. Zarządzanie Zasobami Ludzkimi, 6, 55-65.

Kuczerska, D. (2018). Methods of Looking for a Job in the Modern Labor Market: Analysis of Research on Professional Drivers. Indian Journal of Computer Science, 3(1), 31-36. https://doi.org/10.17010/ijcs/2018/v3/i1/121855

Kuczerska, D., \& Smoląg, K. (2018). Oferty pracy a oczekiwania potencjalnych pracowników z pokolenia Y i Z. Zeszyty Naukowe Politechniki Częstochowskiej Zarządzanie, 31, 134-144. https://doi.org/10.17512/znpcz.2018.3.11

Kulhánek, L., \& Sulich, A. (2018). Financial risk in the contemporary environment of enterprises. Zeszyty Naukowe Wyższej Szkoty Humanitas Zarzadzanie. https://doi.org/10.5604/01.3001.0012.2038

Laszlo, C. (2008). Sustainable value. Problemy Ekorozwoju. https://doi.org/10.4324/9781351280082

Laszlo, C., Sherman, D., \& Whalen, J. (2006). Creating competitive advantage: The sustainable value model. In Management Models for Corporate Social Responsibility. https://doi.org/10.1007/3-540-33247-2_41

Loknath, Y., \& Abdul Azeem, B. (2017). Green Management-Concept and Strategies. National Conference on Marketing and Sustainable Development, 688-702. Retrieved from http://www.aims-international.org/myconference/cd/PDF/MSD4-6111Done.pdf

Marchington, B. (2010). Connecting employees and customers for a better society. Retrieved from https://issuu.com/brettminchington/docs/south-africa_minchington_employer-branding-3.0_hr_

Marciniuk-Kluska, A. (2013). Environmental management in the scope of economic sustainable development. Zeszyty Naukowe Uniwersytetu Przyrodniczo-Humanistycznego w Siedlcach, 23(96), 129-140. Retrieved from http://yadda.icm.edu.pl/yadda/element/bwmeta1.element.ekon-element-000171242281

Marka Pracodawcy. (2019). Energetyka szykuje się na nowe pokolenie.

Masdar. (2019). Gen Z Survey. Retrieved from https://masdar.ae/en/strategic-platforms/youth-4-sustainability/gen-z-survey

Michalski, G. (2012). After-crisis relation between general economic condition and liquidity management: Financial Liquidity Investment Efficiency Model (FLIEM) Use to Diagnose Polish Economics Standing. In 25th Australasian Finance and Banking Conference 2012. https://doi.org/10.2139/ssrn.2137173

Ministerstwo Finansów. (2019). Badania świadomości ekologicznej Polaków.

Moroko, L., \& Uncles, M. D. (2008). Characteristics of successful employer brands. Journal of Brand Management, 16(3), 160175. https://doi.org/10.1057/bm.2008.4

MPWiK. (2019a). Działamy w sposób odpowiedzialny społecznie i troszczymy się o środowisko naturalne. Retrieved from https://www.mpwik.wroc.pl/csr/

MPWiK. (2019b). Strategia. Retrieved from https://www.mpwik.wroc.pl/o-nas/misja-wizja-strategia/

Patel, D. (2017). 11 Environmental Causes Gen Z Is Passionate About. Retrieved from https://www.forbes.com/ sites/deeppatel/2017/10/04/11-environmental-causes-gen-z-is-passionate-about/\#6cbfd8ef1849

Pawłowski, A. (2011). Sustainable development as a civilizational revolution: A multidisciplinary approach to the challenges of the 21st century. London: CRC Press, Taylor and Francis Group. https://doi.org/10.1201/b11326

Poskrobko, B. (1996). Zarządzanie ekologiczne w przedsiębiorstwie jako narzędzie wdrażania ekorozwoju. In Mechanizmy $i$ uwarunkowania ekorozwoju.

Prószynski, J. (2019). Rynek pracy staje na głowie, czyli o employer brandingu słów kilka. Retrieved from https://pijarukoksu.pl/rynek-pracy-staje-glowie-employer-brandingu-slow.html

Rowley, J. (2002). Using case studies in research. Management Research News, 25(1), 16-27. https://doi.org/10.1108/01409170210782990

Rutkowska-Podołowska, M., \& Sulich, A. (2016). Zielone miejsca pracy w gospodarce. In H. Howaniec, Z. Malara, \& J. WyródWróbel (Eds.), Poprawa efektywności w przedsiębiorstwie - wybrane perspektywy (pp. 165-176). Bielsko-Biała. https://doi.org/10.18276/sip.2016.44/3-16 
Rutkowska-Podołowska, M., Sulich, A., \& Szczygieł, N. (2016). Green jobs. In E. Kovářová, L. Melecký, \& M. Staníčková (Eds.), Proceedings of the 3rd International Conference on European Integration 2016, ICEI 2016 (pp. 822-829). Ostrava: VŠB Technical University of Ostrava.

Ryszawska, B. (2016). Sustainability transition needs sustainable finance. Copernican Journal of Finance \& Accounting. https://doi.org/10.12775/CJFA.2016.011

Seemiller, C., \& Grace, M. (2016). Generation Z Goes to College. Jon Willey \&Sons.

Stańczyk-Hugiet, E. (2009). Knowledge-based processes - A strategic perspective. Argumenta Oeconomica.

Stuss, M. (2016). Narzędzia Employer Branding W Praktyce Wybranych Banków. Zeszyt Naukowy Wyższej Szkoły Zarządzania i Bankowości w Krakowie, (40), 18-27. Retrieved from http://cejsh.icm.edu.pl/cejsh/element/bwmeta1.element.desklight0962c0c6-5b02-4b3a-ad26-e34cfc360528

Stuss, M., \& Herdan, A. (2017). External employer branding tools used for attracting graduates by energy companies listed at Warsaw stock exchange. In Proceedings of 8th Economics \& Finance Conference (pp. 200-213). London. https://doi.org/10.20472/efc.2017.008.013

Sulich, A. (2017). Zielone miejsca pracy - diagnoza sytuacji studentów i absolwentów Politechniki Wrocławskiej. Studia Ekonomiczne. Zeszyty Naukowe Uniwersytetu Ekonomicznego w Katowicach, 9(315), 139-149.

Sulich, A. (2018). The Green Economy Development Factors. In Vision 2020: Sustainable Economic Development and Application of Innovation Management from Regional expansion to Global Growth. (pp. 6861-6869). Proceedings of the 32nd International Business Information Management Association.

Sulich, A., \& Zema, T. (2018). Green jobs, a new measure of public management and sustainable development. European Journal of Environmental Sciences. https://doi.org/10.14712/23361964.2018.10

Sulich, A., Zema, T., Kozikowski, K., \& Stasiński, T. (2016). Mój idealny pracodawca 2016. Wrocław. https://doi.org/10.13140/RG.2.2.10156.92804

Sullivan, J. (2007). Green recruiting: building your environmental employment brand. Retrieved from https://www.ere.net/greenrecruiting-building-your-environmental-employment-brand/

Tauron. (2019a). O Tauronie. Retrieved from https://www.tauron.pl/tauron/o-tauronie

Tauron. (2019b). Tauron dla otoczenia. Retrieved from https:/www.tauron.pl/tauron/o-tauronie/tauron-dla-otoczenia/strategiazrownowazonego-rozwoj

The World Commision on Environemnt and Development. (1987). Our common future. Oxford: Oxford University Press.

Tutaj, J., Rutkowska, M., \& Sulich, A. (2019). Eco-innovation as an Element of Business Value and Performance Management. In P. Jedlicka, P. Maresova, \& I. Soukal (Eds.), Hradec Economic Days (pp. 466-474). Hradec Kralove.

UNEP. (2008). Green jobs: towards decent work in a sustainable, low-carbon world. New Solutions : A Journal of Environmental and Occupational Health Policy: NS.

Vitouladiti, O. (2014). Content Analysis as a Research Tool for Marketing, Management and Development Strategies in Tourism. Procedia Economics and Finance, 9, 278-287. https://doi.org/10.1016/s2212-5671(14)00029-x

Wielewska, I. (2019). Selected Ecological Factors and Social Responsibility of Agribusiness Enterprises from Pomorskie Province. In P. Jedlicka, P. Maresova, \& I. Soukal (Eds.), Hradec Economic Days (pp. 521-532). Hradec Kralove: University of Hradec Kralove.

Wojtaszczyk, K. (2015). Zewnętrzny employer branding i rekrutacja relacyjna jako przykłady wykorzystania marketingu w zarządzaniu zasobami ludzkimi. Organizacja i Kierowanie, 4, 181-190.

Yin, R. K. (2017). Case study research and applications: Design and methods. Sage Publications. https://doi.org/10.1016/j.jada.2010.09.005

Żarczyńska-Dobiesz, A., \& Chomątowska, B. (2014). Pokolenie "Z" na rynku pracy - wyzwania dla zarządzania zasobami ludzkimi. Zeszyty Naukowe Uniwersytetu Ekonomicznego We Wrocławiu, 350, 405-415. https://doi.org/10.15611/pn.2014.350.36

Zbaraszewski, W. (2011). Opinie studentów kierunku ekonomia na temat ide i zasad zrównowazonego rozowju. Folia Pomeranae Universitatis Technologiae Stetinensis, 287(63), 277-292. 